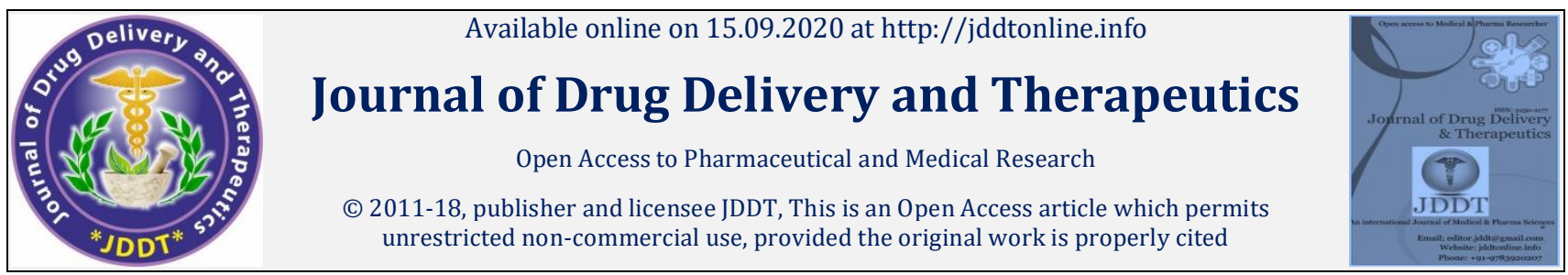

Open Access

\title{
A Review on Pharmacological Aspects of Pyrimidine Derivatives
}

\author{
Vishal Verma ${ }^{1 *}$, Chandra Prakash Joshi' ${ }^{1}$, Alka Agarwal' ${ }^{1}$, Sakshi Soni ${ }^{2}$, Udichi Kataria ${ }^{3}$ \\ 1 U S Ostwal Institute of Pharmacy, Mangalwad, Chittorgarh, (Raj.), India \\ 2 Pacific College of Pharmacy Udaipur, Rajasthan, India \\ ${ }^{3}$ Geetanjali Institute of Pharmacy Udaipur Rajasthan, India
}

\begin{abstract}
Pyrimidine is an aromatic heterocyclic organic compound similar to pyridine. One of the three diazines (six-membered heterocyclics with two nitrogen atoms in the ring), it has the nitrogens at positions 1 and 3 in the ring. Pyrimidines are typically synthesized by the "Principal Synthesis" involving cyclization of beta-dicarbonyl compounds with N-C-N compounds. Reaction of the former with amidines to give 2substituted pyrimidines, with urea to give 2-pyrimidiones, and guanidines to give 2-aminopyrimidines are typical. Pyrimidines can be prepared via the biginelli reaction. Many other methods rely on condensation of carbonyls with diamines for instance the synthesis of 2-Thio-6methyluracil from thiouria and ethyl acetoacetate or the synthesis of 4-methylpyrimidine with 4, 4-dimethoxy-2-butanone and formamide. Pyrimidine derivatives show antimicrobial activity, anticancer activity, anti-inflammatory activity, antidiabetic, and analgesic activity. ${ }^{1}$
\end{abstract}

Keywords: Pyrimidine derivatives, Synthesis, derivatives and pharmacological activities.

Article Info: Received 14 July 2020; Review Completed 19 August 2020; Accepted 27 August 2020; Available online 15 Sep 2020

\section{Cite this article as:}

Verma V, Joshi CP, Agarwal A, Soni S, Kataria U, A Review on Pharmacological Aspects of Pyrimidine Derivatives, Journal of Drug Delivery and Therapeutics. 2020; 10(5):358-361 http://dx.doi.org/10.22270/jddt.v10i5.4295

*Address for Correspondence:

Vishal Verma, U S Ostwal Institute of Pharmacy, Mangalwad, Chittorgarh, (Raj.), India

\section{INTRODUCTION}

Pyrimidine is an aromatic heterocyclic organic compound similar to pyridine. One of the three diazines (six-membered heterocyclics with two nitrogen atoms in the ring), it has the nitrogens at positions 1 and 3 in the ring. ${ }^{2}$ The other diazines are pyrazine (nitrogens 1and 4), pyridazine (nitrogens 1 and 2). Pyrimidine ('m diazine') were known as the breakdown products of uric acid. The fist pyrimidine derivative to be isolateted was alloxan in 1818 by brugnateli. The name pyrimidine (combination of words pyridine and amidine) was first applied by Pinner ${ }^{3}$.<smiles>c1cncnc1</smiles>

Pyrimidine

Nucleic acid hydrolysis produces several pyrimidines (uracil, thymine and cytosine) the two types of nucleic acid DNA and RNA, cytosine is found present in both DNA and RNA, while uracil present only in RNA and thymine only in DNA 4 .

ISSN: $2250-1177$

\section{PROPERTIES}

Physical Properties

\begin{tabular}{|l|l|}
\hline Molecular formula & $\mathrm{C}_{4} \mathrm{H}_{4} \mathrm{~N}_{2}$ \\
\hline Molar mass & $80.088 \mathrm{~g} \mathrm{~mol}^{-1}$ \\
\hline Density & $1.016 \mathrm{~g} \mathrm{~cm}^{-3}$ \\
\hline Melting point & $20^{\circ} \mathrm{C}\left(68^{\circ} \mathrm{F} ; 293 \mathrm{~K}\right)$ \\
\hline Boiling point & $123^{\circ} \mathrm{C}\left(253^{\circ} \mathrm{F} ; 396 \mathrm{~K}\right)$ \\
\hline Acidity $\left(\mathrm{p} K_{\mathrm{a}}\right)$ & 1.10 (protonated pyrimidine) \\
\hline
\end{tabular}

Like pyridines, in pyrimidines the $\pi$-electron density is decreased to an even greater extent.

Therefore electrophilic aromatic substitution is more difficult while nucleophilic aromatic substitution is facilitated. An example of the last reaction type is the displacement of the amino group in 2-aminopyrimidine by chlorine-and its reverse. 5

Electron lone pair availability (basicity) is decreased compared to pyridine. Compared to pyridine, N- 
alkylation and N-oxidation are more difficult. The pka value for protonated pyrimidine is 1.23 compared to 5.30 for pyridine. Protonation and other electrophilic additions will occur at only one nitrogen due to further deactivation by the second nitrogen. The 2-, 4-, and 6- positions on the pyrimidine ring are electron deficient analogous to those in pyridine and nitro- and dinitrobenzene. ${ }^{6}$ The 5 -position is less electron deficient and substitutents there are quite stable. However, electrophilic substitution is relatively facile at the 5-position, including nitrogen and halogenations. ${ }^{7}$

Reduction in resonance stablisation of pyrimidines may lead to addition and ring cleavage reactions rather than substitutions. One such manifestation is observed in the Dimer other arrangement. 8

\section{SYNTHESIS}

As is often the case with parent hetero cyclic ring systems, the synthesis of pyrimidine is not that common and is usually performed by removing functional groups from derivatives. Primary syntheses in quantity involving formamide have been reported. ${ }^{9}$

As a class, pyrimidines are typically synthesized by the "Principal Synthesis" involving cyclization of beta-dicarbonyl compounds with N-C-N compounds. Reaction of the former with amidines to give 2-substituted pyrimidines, with urea to give 2-pyrimidiones, and guanidines to give 2aminopyrimidines are typical. 10

Pyrimidines can be prepared via the biginelli reaction. Many other methods rely on condensation of carbonyls with diamines for instance the synthesis of 2-Thio-6-methyluracil from thiouria and ethyl acetoacetate or the synthesis of 4 methylpyrimidine with 4, 4-dimethoxy-

\section{2-butanone and formamide. ${ }^{11}$}

A novel method is by reaction of certain amides with carbonitriles under electrophilic activation of the amide with 2-chloro-pyridine and trifluromethane sulfonic anhydride. ${ }^{12}$

\section{Biginelli Reaction}<smiles>CCOC(=O)C1=C(C)NC(=O)NC1c1ccccc1</smiles>

\section{Derivatives}

Three nucleobases found acid,cytocine $(\mathrm{C})$, thymine $(\mathrm{T})$, and uracil $(\mathrm{U})$, are pyrimidine derivatives:[13]<smiles>Cc1c[nH]c(=O)[nH]c1=O</smiles>

Cytosine Thymine<smiles>O=c1cc[nH]c(=O)[nH]1</smiles>

Uracil
In DNA and RNA, these bases form hydrogen bond with their complementary purines. Thus, in DNA, the purines adenine $(\mathrm{A})$ and guanine $(\mathrm{G})$ pair up with the pyrimidines thymine (T) and cytosine (C), respectively. In RNA, the complement of adenine (A) is uracil (U) instead of thymine (T), so the pairs that form are adenine: uracill and guanine: cytosine very rarely, thymine can appear in RNA, or uracil in DNA. Other than the three major pyrimidine bases presented, some minor pyrimidine bases can also occur in nucleic acid. These minor pyrimidines are usually methylated versions of major ones and are postulated to have regulatory functions. ${ }^{14}$

These hydrogen bonding modes are for classical watsoncrick base paring. Other hydrogen bonding modes ("wobble pairings") are available in both DNA and RNA, although the additional 2'-hydroxyl group of RNA expands the configurations, through which RNA can form hydrogen bonds ${ }^{15}$

\section{PHARMACOLOGICAL ACTIVITIES}

\section{Antimicrobial Activity}

Microbes are causative agents for various types of disease like pneumonia, amoebiasis, typhoid, malaria, common cough and cold various infections and some severe diseases like tuberculosis, influenza, syphilis, and AIDS as well. Various approaches were made to check the role of pyrimidine moiety as antimicrobial agent from the discovery of molecule to the present scenario. ${ }^{16}$

Hitchings, in 1948, made an important observation that a large number of 2, 4 diamino pyrimidines and some 2amino- 4 hydroxy pyrimidines are antagonists of folic acid. These pyrimidines were than eventually proved as inhibitors of the enzyme dihydrofolate reductase (DHFR). Amongst the2, 4-diaminpyrimidine drugs, pyrimethamine is selective inhibitor of the DHFR of malarial plasmodia. ${ }^{17}$

Trimethoprim, antibacterial drug is also a selective inhibitor and selectively inhibits bacterial DHFR.<smiles>C1CC2CCC1C2</smiles><smiles>COc1cc(Cc2cnc(N)nc2N)cc(OC)c1OC</smiles>

Trimethoprim

Brodimoprim, is also found to be an effective antibacterial compound.<smiles>COc1cc(Cc2cnc(N)nc2N)cc(OC)c1Br</smiles>

Pyrimidine also shows antifungal properties. Flucytosine is a fluorinated pyrimidine used as nucleosidal anti fungal agent for the treatment of serious systemic infection caused by susceptible strains of candida and Cryptococcus .18 


\section{Anticancer Activity}

The pyrimidine moiety with some substitution shows promising antitumor activity as there are large numbers of pyrimidine based antimetabolites. The structural modification may be on the pyrimidine ring or on the pendant sugar groups. Early metabolite prepared was 5fluorouracil, a pyrimidine derivative followed by 5Thiouracil which also exhibits some useful anti- neoplastic activities.$^{19}$<smiles>O=c1[nH]cc(S)c(=O)[nH]1</smiles>

\section{5- Thiouracil}<smiles>O=c1[nH]cc(F)c(=O)[nH]1</smiles>

\section{5-Flurouracil}

Reacted 5 benzoyl/ 5-carbaldehyde-/ 5- (3- phenyl acryloyl o- 6- hydroxy-1H-pyrimidine-diones with amines provided the corresponding enamines. The investigation for anticancer activity of molecule at 59 human tumor cell lines was done representing leukemia, melanoma and cancer of lung, colon, brain, ovary, breast as well as kidney.

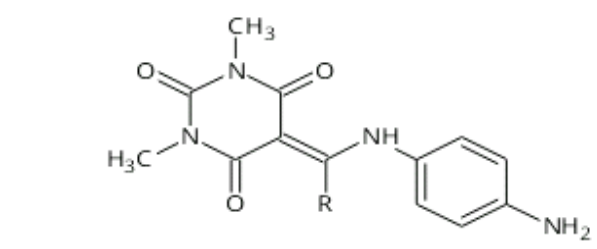

$\mathrm{R}=\mathrm{H}, \mathrm{CH}=\mathrm{CH}-\mathrm{Ph}, \mathrm{Ph}$

Synthesized 4-(2-Methylanilino) benzo[b] thieno [2, 3-d] pyrimidine (1) and 4- (2-Methoxy anilino) benzo [b] thieno[2, 3-d] pyrimidine (2) which showed a similar cytotoxicity to the standard anti-EGFR geftinib suggesting a blockade of the EGFR pathway by binding to the tyrosine kinase receptor. 20

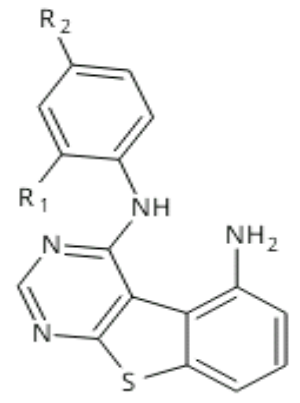

$$
\begin{array}{ll}
\mathrm{R}_{1}=\mathrm{CH}_{3} & \mathrm{R}_{2=} \mathrm{H} \text { for }(1) \\
\mathrm{R}_{1}=\mathrm{OCH}_{3} & \mathrm{R}_{2=} \mathrm{H} \text { for }(2)
\end{array}
$$

Synthesized a series of some new pyrimidine derivatives like 7-(2-methoxy phenyl)-3 methyl- 5-thioxo-5, 6-dihydro[1, 2, 4]-triazolo[4, 3-c]pyrimidine-8-carbo-nitrile via reaction of ethylcyanoacetate with thioureaand the appro- priate aldehydes namely 2-methyl-benzaldehyde and 2methoxybenz- aldehyde followed via reaction with different reagents. All structures were than screened for bacterial activity and anticancer activity.<smiles>COc1ccccc1-c1[nH]c(=S)n2c(C)nnc2c1C#N</smiles>

Organic compounds and their complex with various ligands have found many applications in biomedicine. describe the preparation of $\mathrm{R} 2 \mathrm{SnCl} 2$ complex of some $4 \mathrm{H}$-pyrido [1,2-a] pyrimidin-4-one derivatives as donating ligand having multiple donor sites and examine the cytotoxic activity of some of these complex against fine tumor cell lines.

\section{Anti-Inflammatory Activity}

Pyrimidine has a remarkable pharmacological efficiency and therefore an intensive research has been focused on anti inflammatory activity of pyrimidine nucleus. Recently two PCT international applications have been filed for 2thiopyrimidine derivatives possessing potent activity against inflammation and immune disorders .pyrimidine was reported by Padama shale et al. Carrageen induced rat paw edema method was employed for evaluating the antiinflammatory activity. The compounds were given at a dose of $80 \mathrm{mg} / \mathrm{kg}$ body weight in albino rats weighing between 150 and $200 \mathrm{~g}$. The edema was produced by injecting carrageenan solution at the left hind paw.<smiles>[R]c1nc([R])c2oc3c4ccccc4ccc3c2n1</smiles>

$$
\mathrm{R}=\mathrm{CH}_{3}, \mathrm{C}_{6} \mathrm{H}_{5} ; \mathrm{R}_{1}=\mathrm{OCH}_{3}, \mathrm{OC}_{2} \mathrm{H}_{5}, \mathrm{NHC}_{2} \mathrm{H}_{5}, \mathrm{NHC}_{6} \mathrm{H}_{5}
$$

Synthesized somesubstituted thieno pyrimidines-4-one and screened then for analgesic and anti-inflammatory activity. ${ }^{21}$<smiles>[R]C1=C([R])C2NC([R])N(N)C(=O)C2S1</smiles>

$$
\mathrm{R}_{1}, \mathrm{R}_{2}=-\left(\mathrm{CH}_{2}\right)_{3},-\left(\mathrm{CH}_{2}\right)_{5},-\left(\mathrm{CH}_{2}\right)_{4} ; \mathrm{R}_{3}=\mathrm{CH}_{3}
$$

\section{Antidiabetic Activity}

Synthesized some novel pyrimidines derivativehaving thiazolidine dione. These compounds were evaluated for their glucose and lipid lowering activity using pioglitazone and rosiglitazone as reference compound. Synthesized azolopyrimidine derivatives and compounds were evaluated for hypoglycemic activity. ${ }^{22}$ 


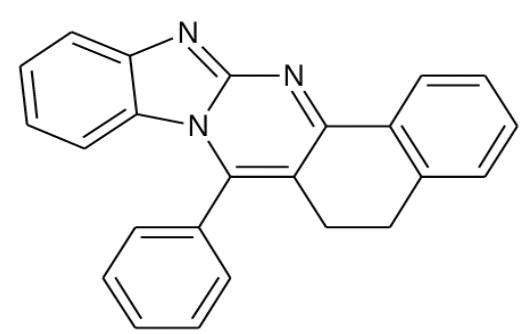

Azolopyrimidine

\section{Analgesic Activity}

New forms of thiamine are lipidsoluble like acetiamine, Benti- amine etc., having therapeutic use in beriberi, polyneuritis, encephalopathy, pain, malnutrition and alcoholism and especially in the treatment of long-standing insulin-dependent diabetes mellitus.

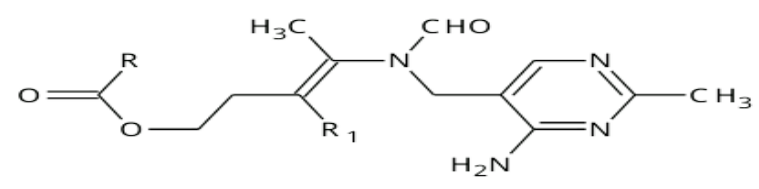

$\mathbf{R}$

$\mathrm{R}_{1}$

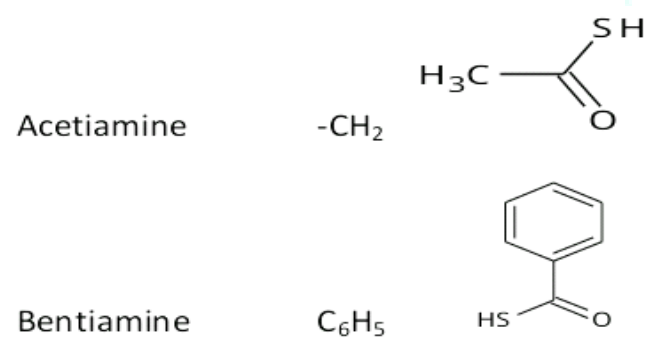

Synthesized substituted thieno [2, 3-d] pyrimidine- 4(3H)ones and then screened them for analgesic active.<smiles>[R]NC1Nc2sc([R](=O)[O-])c(C)c2CN1[R]</smiles>

$$
\mathrm{R}=-\mathrm{CH}_{3},-\mathrm{NHPh} ; \mathrm{R}_{1}=\mathrm{R}_{2}=\mathrm{Ph}, \mathrm{o}-\text { Anisyl }
$$

Anti-inflammatory and analgesic activity of synthesized pyrimidine derivatives.<smiles>CC(=O)Nc1ccccc1N1C=CCNC1=S</smiles>

(1)<smiles>O=[N+]([O-])c1ccc(NN2C=CCNC2=S)c([N+](=O)[O-])c1</smiles>

(2)
Synthesized some new 2-[c]-phenyl- $1 \mathrm{H}$ - pyrazolo [3, 4- d] pyrimidin- $4 \mathrm{yl}$ ) Acetohydrazide derivative have been prepared and screened for their analgesic activity by acetic acid induced writhing test using standard drug diclofenac sodium. ${ }^{23}$<smiles></smiles>

Acetohydrazine

\section{CONCLUSION}

Pyrimidines occupy a distinct and unique place in our life. This heterocyclic moiety has great biological and medicinal significance. A vast literature has been accumulated over the years and chemistry of pyrimidines continues to be a blossoming field. The biological profiles of this new generation of pyrimidine represent much progress with regard to the older compounds.

\section{REFERENCES}

1. Delgado JN and Remers WA; Wilson and Giswold's Textbook of Organic Chemistry Medicinal and Pharmaceutical Chemistry; 10th ed. Philadelphia:Lippincott Raven; 1998.

2. Miller D; Remington- The Science and Practice of Pharmacy; 19th ed. Pennsylvania: MACK Publishing Company; 1995; 425.

3. Amir M, Javed SA and Kumar H; Indian J. Pharm. Sciences; 2007; 69(3):337-343.

4. Cox RA; Quart. Rev.; 1968; 22:499.

5. Jain MK, Sharnevas SC; Organic Chem.; 2008; 3:997-999.

6. Eussell JA; Annu. Rev. Biochem.; 1945; 14:309.

7. Hitchings GH, Elion GB, Wanderers $\mathrm{H}$ and Falco EA; J. Biol. Chem.; 1948; 174:765.

8. Futterman S; J. Biol. Chem.; 1957, 228:1031.

9. Cheng CC and Roth B; In Progress in Medicinal Chem. (eds Ellis GP and West GB), Butterworths London; 1982; 19:267.

10. Kompis I and Wick A; Helv. Chim. Acta; 1977; 60; 3025.

11. Polak A. and Scholer HJ; Chemotherapy; 1975; 21:113.

12. Padamshari B, Vaidya VP and Vijayayakumar ML; Indian J.Hetero. Chem.; 2002; 12:89-94.

13. Naik TA and Chikhalia KH; E-Journal of Chem.; 2007; 4(1):6066.

14. Aly and AA, Chinese J. of Chem.; 2005; 23:211-217.

15. Mogilaiah K and Sudhakar GR; Indian J. Hetero. Chem.; 2003; 42B:636-640.

16. Mishra A and Singh DV; Indian J. Hetero. Chem.; 2004; 14:43-46.

17. Russo F, Romeo G, Caruso A, Cutuli V, Amore D and Santagati NA; Eur. J. Med. Chem.; 1999; 29:569.

18. Cenicola, Donnoli D, Stella L, Paola CD, Constantino $\mathrm{M}$, Anignente E, Arena F, Luraschi E and Saturnino C, Pharmacology Res.; 1990; 22:80.

19. Nargund LVG, Badiger VV and Yarnal SM; J. Pharm. Sci.; 1992; 81:365.39. Rashand.

20. Honkanen E, Pipuri A, Kairisalo P, Nore P, Karppaness H and Paakari I; J. Med. Chem.;1983; 26:143.

21. Mery Press B, James Mc Nally J, Joan Keisher A, Steve Offord J, Laurence Katz B, Robert Falotico and Alfonso Tobaia J; Eur. J. Med Chem.; 1989; 24:627.

22. Ronald Russell K, Jeffery Press B, Richard Rampulla A, James Mcnally J, Robert Falotico, Joan Keiser A, David Bright A and Alfonso Tobia; J. Med. Chem.; 1988; 31:1786.

23. Ganzevoort W, Rep A, Bonsel G.J, De Vries JI and Wolf H; Hypertension; 2004; 22:1235-1242. 